\title{
CINCO ENGANOS COM UMA OBRA SÓ
}

\author{
SHEILA LEIRNER conta como se equivocou repetidas vezes com a \\ Guernica, de Picasso
}

\author{
"Mais difícil fazer uma coisa do que falar sobre ela? De jeito nenhum. \\ Aí está um estúpido equívoco popular! É muito mais difícil falar sobre \\ uma obra do que fazê-la."[1] \\ "Erros de julgamento não são naturais? Fazer crítica é tão fácil? A \\ verdadeira crítica de arte não é tão rara quanto a arte?(...)"[2]
}

Dentro do tema proposto preferi evocar os "equívocos de percepção" que mudam de figura com o tempo, às vezes podem durar a vida inteira e levar, de fato, a "equívocos críticos". Isso, até mesmo em relação a uma única obra.

Nesse sentido, nada mais nada menos do que a Guernica, de Picasso, sofreu cinco equívocos de minha percepção. O primeiro passou-se em 1953, na segunda Bienal de São Paulo, quando eu media 1 metro e 8 centímetros, pesava cerca de 16 quilos e - enquanto a olhava - meus pais me seguravam pela mão. Pelo que tinha ouvido antes em casa, compreendi apenas que estava vivendo um momento extraordinário diante da "pintura mais importante do mundo", feita pelo "pintor mais genial do universo".

Naquela idade, evidentemente, eu não podia saber o que a tela tinha[3]. Nem imaginava o que era uma bomba, quanto mais conhecer o sentido das palavras "denúncia" e "engajamento" como os adultos definiam a ação pictórica do artista. E o que era a pintura "moderna" da qual falavam tanto na hora do almoço?

Eu julguei a tela gigantesca, deslumbrante, assustadora e totalmente incompreensível comparada às imagens que eu via nos filmes de 
desenhos animados ou nas histórias em quadrinhos. Além do que, quando pensava no quadro depois, sempre o via muito colorido.

Quantos segredos seriam desvendados se ouvíssemos as vozes da inocência... O pintor Philip Guston costumava dizer que queria pintar como se fosse "a primeira vez". Dizia que "a pintura é uma ilusão, um passe de mágica, de forma que o que você vê não é o que você vê". Bem ou mal, com ou sem equívocos, quem pode percebê-la originalmente, se não os que foram privados do "conhecimento"?

O meu segundo equívoco com a Guernica foi em Nova York. Aos 16 anos, aquela cidade tinha sobre mim o mesmo efeito de uma bola de cristal de Murano. Pura felicidade e exaltação! Mescla de inquestionável fascínio com apreensão, uma espécie de desejo abstrato e impaciente que eu não conseguia discernir e que me causava até mesmo desconforto. Eu seria capaz de mergulhar e divagar infinitamente naquela paisagem de sonho à procura das estórias que imaginava existir dentro de cada janela, que para mim nada mais era do que uma bolha de luz! Diante do sonho absoluto dos arranha-céus e aglomerados, como encarar o "pesadelo" de destruição urbana da Guernica que agora se encontrava lá?[4]

Eu já media 1 metro e 65 centímetros, estava com alguns quilos abaixo do meu peso normal e, enquanto constatava que a tela não era colorida e nem tão gigantesca, na sala ainda não reformada do MoMA (Museum of Modern Art) meu irmão, adolescente, pulava em volta de mim para afastar o meu mau humor. Eu que, segundo nossa mãe, "precisava me entusiasmar", tinha ficado bastante cansada no andar de baixo, visitando a primeira exposição coletiva dedicada à Pop Art, do museu.

Era 1964 e eu sabia que fora dali existiam várias outras coisas interessantes para me entusiasmar.[5] Com a minha pouca idade, já havia testemunhado ou captado, sem saber precisamente, certas revelações do contexto artístico da época.[6] Como não me cansar com aquela enciclopédica e repetitiva exposição Pop do MoMA? 
Naturalmente, além de confirmar que a Guernica tinha sido pintada como se fosse uma fotografia em branco e preto com nuances de cinza, e de me certificar que os 349,3 x 776,6cm dela não eram tão monumentais quanto uma criança de 1 metro e 8 centímetros podia imaginar, não consegui ver mais nada, pois meu irmão já saía apressado da sala, minha mãe atrás dele, os dois fazendo menção de passar pelo mural Suicídio coletivo, de David Alfaro Siqueiros, com o intuito de colocar o pé na escada rolante.

\section{"(...) A crítica não é inocente. Vinda de um dado contexto, deve ser relativa, política, parcial, injusta, imperfeita. Jamais lucrativa".[7]}

O meu terceiro equívoco com a Guernica já começava a fazer parte da série de outros prováveis erros de compreensão (e também de apreciação) que devo ter cometido desde então, pelo simples fato de que já era, de fato, crítica de arte.

Eu media 1 metro e 66 centímetros, estava alguns quilos acima do meu peso normal e - enquanto olhava o quadro, de novo no MoMA - o amigo com quem eu me encontrava se queixou de fome. Eu tentava observá-la, mas ele disse: "Vamos? Vamos àquele nosso lugar comer hambúrguer?". "Aquele nosso lugar" era o P.J. Clarke's, em Nova York, o melhor hambúrguer do final dos anos 70 - de modo que a pergunta não era blasfêmia, mesmo (ou sobretudo) diante de Picasso, que adorava viver e portanto comer bem. Como exigir atenção estética a um homem, mesmo que ele seja amador e experto de arte, no momento em que a sua concentração só pode estar voltada ao estômago?

Pedi alguns minutos, explicando que, se eu não conseguisse olhar atentamente a obra antes de voltar ao Brasil no dia seguinte, seria a terceira vez que ela me escaparia. O fato é que, sob pressão, naqueles minutos só consegui registrar na minha memória, de maneira aproximativa, o que a tela contém.[8]

Sair de uma experiência estética com a descrição pura e simples do que se 
viu, sem conseguir entrar nas relações formais e significados, foi sem dúvida um equívoco bastante significativo. E um castigo também, pois, por causa da indesculpável fraqueza terrena, um ligeiro sentimento de culpa me perseguiu durante as quase três décadas seguintes, a cada vez que eu via uma reprodução dela.

\footnotetext{
"Apenas o crítico não se comporta como o artista. Ele não tem obra de arte a fazer. Não vê obra de arte em sua frente. Ele vê todas as obras de arte atrás dele, como coisas já feitas."[9]
}

O meu penúltimo erro com a Guernica ocorreu em julho de 2008. Decidi ver a tela sozinha, já no Reina Sofia[10] em Madri. Nada mais no mundo, pensava eu, poderia perturbar o nosso momento de intimidade. Finalmente, Guernica e eu!

Era cedo e até mesmo a sala quase vazia do museu contribuía para o reencontro. Fiquei, de fato, tão comovida que não conseguia concatenar as idéias. Pior do que isso, eu via sem ver por causa da emoção de estar em momento e lugar tão esperados. Não me espanta que o meu cérebro vazio tivesse sido invadido, então, pelas imagens de um trabalho de apropriação em 3D que havia me indignado pouco antes.

Eu olhava a Guernica e só via aquele Exploration of Picasso's Guernica, da alemã Lena Gieseke[11]. Refazia a tela inteira, como ela, transformandoa, na minha imaginação, em videoclipe tridimensional. Justo eu, para quem assistir a deturpação da Guernica tinha sido mil vezes mais triste do que ouvir os remixes musicais em que os DJ's desrespeitam compositores e intérpretes!

O que restava do sentido trágico, paradoxalmente aprofundado pelo achatamento das formas e pelas cores sombrias da obra do gênio? Onde estavam a incisão e a virtualidade violenta do traço e dos volumes que transformam o manifesto em grito surdo? Ao dar volumes reais aos volumes virtuais de Picasso, a transformar a obra-prima que é Guernica em assombroso e gratuito exercício técnico, a moça esvaziava totalmente 
a linguagem do mestre!

Quando desisti de ficar inutilmente em pé diante do quadro e fui ao pátio interno do museu me despedir do Oiseau lunaire, de Miró, só conseguia imaginar Picasso comunicando-se mediunicamente com Lena Gieseke e se revirando no seu túmulo[12]... "Se alguém personificou e fundou o espírito crítico, dizia Albert Thibaudet[13], foi Sócrates, que sabia tão bem que não sabia nada". Deixei Madri, com a estranha sensação de não ter estado lá.

\footnotetext{
"A arte celta-gaulêsa está, ao mesmo tempo, tão longe e tão próxima de nós, é tão arcaica e tão moderna, que tivemos que esperar as últimas conquistas da arte moderna para compreendê-la."[14]

"Se, ao menos, me fosse concedido tempo suficiente para terminar a minha obra, não deixaria eu, primeiro, de nela marcar a chancela deste Tempo cuja ideia hoje se impõe a mim, com tanta força (...)"[15]
}

O meu último equívoco com a Guernica aconteceu em junho deste ano. Voltei ao Reina Sofia para ver a exposição de Cildo Meireles e, é claro, para tentar remediar os mal-sucedidos encontros com ela em minha vida. Qual o quê! A sala estava repleta de turistas, era impossível nos aproximarmos e mal se via a parte inferior do quadro. Menos ainda por mim que, agora, passei a ter 1 metro e 63 centímetros. A minha frustração foi tamanha que me vinguei um pouco fazendo uma (única) foto com o meu telefone - o que me valeu a repreensão severa da vigia em uniforme.

Como se isso não bastasse, um homem francês de óculos, alto e bem vestido, que acabara de se colocar a meu lado para fugir da multidão, não se conteve e disse, em voz alta:

- Oh là là! Estou para ver tela mais feia no planeta!

E não é que ele tinha razão? O tema e as formas que relatam e, ao mesmo 
tempo, expressam a dor dos habitantes de uma cidade destruída pela barbárie não podem ter nada de formoso. Com o seu poder narrativo que continua a suscitar centenas de estudos no mundo inteiro, a Guernica é talvez, efetivamente, a tela mais extraordinária e pavorosa do planeta. Apenas que - mesmo se foi o que suspeitei quando a vi pela primeira vez na minha infância - naquela sala, novamente - eu não consegui atinar por que. Talvez ela seja tão arcaica e contemporânea que, como acontece com a "arte celta-gaulêsa, eu tenha que esperar por mais conquistas da arte contemporânea para compreendê-la". Em todo caso, espero, como Proust, que me seja concedido tempo para um dia concluir alguma coisa e "nela marcar a chancela deste Tempo cuja ideia um dia se imporá a mim".

[1] WILDE, Oscar. O Crítico enquanto Artista.

[2] MIES VAN DER ROHE, Ludwig. Das Kunstblatt, 1930.

[3] Tinha o nome de uma cidade basca bombardeada num ataque aéreo no dia 26 de abril de 1937 por 44 aviões da Legião nazista alemã, 13 aviões da aviação fascista italiana, como apoio ao golpe de Estado nacionalista espanhol.

[4] Pois Picasso havia recusado que a tela voltasse à Espanha enquanto a liberdade civil não fosse restabelecida.

[5] Antes de chegar a Nova York, o governador Nelson Rockfeller e o "curador" da exposição universal, Robert Moses, tinham censurado o famoso Most Wanted Men, mural de Andy Warhol onde ele retratava 13 fugitivos procurados pela FBI. A obra estava instalada justamente na fachada do pavilhão de Nova York, projetado pelo famoso arquiteto Philip Johnson, junto com outros trabalhos de Roy Lichtenstein e Robert Indiana, o que exprimia não só a nova tendência Pop como uma certa impertinência da arte americana daquele tempo. Rockefeller, que certamente não entendia coisa alguma de arte, deu 24 horas para Warhol retirar a obra, pretextando que os tais criminosos já não estavam mais sendo procurados pela polícia e que portanto não havia razão para exibir os seus retratos. Como se vê, os Estados Unidos também são um país de piada pronta! Warhol deve ter compreendido isto, pois propôs a substituição dos delinquentes pela imagem de Robert Moses. Enfim, como ninguém ficou de acordo com aquela proposta subversiva, quando cheguei, lá estava a solução que o artista tinha encontrado para denunciar a censura: uma pintura monocromática de alumínio com a qual cobriu os retratos dos 13 bandidos. Eu adorei!.

[6] A emergência da Pop Art numa conjuntura marcada pela herança do expressionismo abstrato, a emancipação de uma imagética associada à cultura do consumo, o questionar do lirismo da pintura monocromática, a reabilitação do Dada e do modelo duchampiano e, do ponto de vista específico de Warhol, o recurso às técnicas de reprodução mecânica, reciclagem de imagens fotográficas, a predileção pelas iconografias funestas e... o glamour!

[7] MIES VAN DER ROHE, Ludwig. Art Criticism, 1930.

[8] A figura central, iluminada por uma lâmpada, é uma égua aterrorizada cujo corpo, recoberto de linhas verticais, foi transpassado por uma lança. À esquerda, uma mulher carrega a sua criança morta e grita de dor. Atrás dela, está um touro. Embaixo à esquerda, um homem deitado com os braços esticados segura uma espada 
quebrada. Uma pequena flor aparece tímida, quase esmagada entre as patas do jumento e a espada quebrada. Â direita do quadro, três mulheres desconjuntadas, uma delas ferida, choram e gritam; a do alto estende uma lâmpada a óleo em direção ao centro da tela. No fundo, formas geométricas evocam casas incendiadas, sendo que as chamas são representadas por triângulos claros.

[9] THIBAUDET, Albert. Physiologie de la Critique.

[10] Para onde ela tinha voltado em 1981, seis anos depois da morte de Franco como forte símbolo do final de uma longa ditadura e da transição democrática. [11] Fotógrafa que mora em Nova York e foi mulher de Tim Burton.

[12] No parque do castelo Vauvenargues.

[13] Crítico literário francês (1874-1936), que escreveu para a NRF (La Nouvelle Revue Française) de 1912 até a sua morte.

[14] ESTIENNE, Charles. Crítico de arte e escritor francês (1908-1966).

[15] PROUST, Marcel. Em Busca do Tempo Perdido.

SHEILA LeIRNer nasceu em São Paulo. É crítica de arte, jornalista e curadora independente. Vive e trabalha em Paris desde 1991. Publicou Arte como Medida (Perspectiva) e Arte e seu Tempo (Perspectiva), entre outros, e foi curadora de duas Bienais de São Paulo (18 e 19a). 